\title{
Land cover changes in Poland between 1990 and 2012
}

MARTA BOROWSKA-STEFAŃSKA, KATARZYNA LEŚNIEWSKA-NAPIERA $Ł A$, SZYMON WIŚNIEWSKI

University of Łódź, Faculty of Geographical Sciences, Institute of the Built Environment and Spatial Policy, Łódź, Poland; e-mail: marta.borowska@geo.uni.lodz.pl, katarzyna.lesniewska@ geo.uni.lodz.pl, szymon.wisniewski@geo.uni.lodz.pl

ABSTRACT The aim of the article is to assess the intensity and directions of land cover changes in Poland between 1990 and 2012. To achieve this goal, the authors used data from databases such as the CORINE Land Cover (CLC). The changes were analyzed for the first level of data and then presented in the matrix form both as absolute values (ha) and as percentages referring to the total aggregate land surface subject to land cover changes in this period. At the following stage of the analysis attention shifted solely to those fluctuations which referred to artificial surfaces in relation to the municipality or the cadastral unit. Subsequently, a spatial autocorrelation of land cover changes in municipalities in Poland was defined.

KEY WORDS land cover changes - Poland - CORINE - GIS

BOROWSKA-STEFAŃSKA, M., LEŚNIEWSKA-NAPIERAEA, K., WIŚNIEWSKI, S. (2018): Land cover changes in Poland between 1990 and 2012. Geografie, 123, 1, 63-83.

Received June 2017, accepted January 2018.

(C) Česká geografická společnost, z. s., 2018 


\section{Introduction}

Since the beginning of their existence, people have been using land and its resources to satisfy their material, social, cultural and spiritual needs. To achieve this they have changed it in a variety of ways and with different intensity, e.g. natural forests and meadows have been transformed into agricultural land, pastures, residential and industrial areas or infrastructure facilities (Briassoulis 1991). Changes in land cover are a result of complex interaction of many factors, including politics, economy, culture, environment and human behaviour (Vesterby, Heimlich 1991; Meyer, Turner II 1992; Houghton 1994; Medley et al. 1995; Bergeron, Pender 1999; Pijanowski et al. 2002; Li, Wang 2016). Research on the use and development of land became extremely intensive with the advent of methods to assess the development of socio-natural interaction in the second half of the $20^{\text {th }}$ century (Eowicki 2008). Research into changes in land cover in world literature tends to employ analysis in terms of surface only (Meyer, Turner II 1992; Wear, Bolstad 1998; Alphan 2003; Li, Wang 2016; Schaffert, Steensen 2017) or it indicates what form of land cover was implemented in the given modified category (Alphan 2003; Salvati et al. 2012; Du et al. 2014; Grecchiet et al. 2014; Li, Wang 2016). In addition, statistical methods such as simple or multiple regression are used in order to forecast changes in land cover (Wear, Bolstad 1998; Bergeron, Pender 1999; Nguyen 2008; Prishchepov et al. 2013; Stoebner, Lant 2014; Nguyen et al. 2016).

One of the most important pieces of spatial information for land use and development analysis is coverage/use maps. Information on land cover changes is extremely important for understanding the relationships between human and natural phenomena (Lu et al. 2004; Popovici, Bălteanu, Kucsicsa 2013). National Landcover Data (NLCD), a publicly available database covering the continental US at a resolution of $30 \mathrm{~m}$, is a prime example of land coverage maps (Wickham et al. 2004; Dąbrowski 2016). In Poland and other European countries, two collections of data are available for free and widely used: CORINE Land Cover (CLC), which was prepared by the EU under the 'CoORdination of INformation on the Environment' project (Popovici, Bălteanu, Kucsicsa 2013; Dąbrowski 2016), as well as Urban Atlas, a European Commission initiative in cooperation with the European Space Agency (ESA) and the European Environment Agency (EAE; Meirich 2008; Prastacos, Chrysoulakis 2011; Dąbrowski 2016). The CLC database contains extremely useful information on land cover and use (Popovici, Bălteanu, Kucsicsa 2013). It was used to study land use changes by such researchers as Feranec et al. 2000, 2005, 2006, 2007, 2010, 2012, 2016; Feranec, Otahel 2001; Cebecauer, Hofierka 2008; Popovici, Bălteanu, Kucsicsa 2013; Gutman, Radeloff 2017.

When trying to characterize and interpret contemporary social and economic phenomena in Poland in their spatial dimension, it is necessary to bear in mind the array of political changes which took place in the country after 1989. That 
period saw a radical transformation of many elements of the country's social and economic life (Bański 2007). Since 1989, we may include the political transformations and the transition from a centrally planned economy to a market economy, which is connected with a totally new approach to land development.

The most important changes in Poland after 1989 that directly affect land development include: decentralization of the political authority and rebirth of self-governance, privatization and decentralization of the economy, adjustment of legal regulations in the scope of spatial planning to the EU standards and obtaining access to structural funds and agricultural subsidies of the European Union from the moment Poland joined the EU (Węcławowicz et al. 2006).

The second half of the 1990s also marked the beginning of activities aimed at the decentralization of public administration. As a consequence, on 1 January 1999, the 49 existing provinces were liquidated and replaced with 16 larger ones, divided into districts and municipalities. The reform was intended to introduce a transparent division of the tasks between public and self-governance administration. The government and administration on the central level were to restrict its involvement only to issues of national character connected with the state's policy (Wendt 2001, 2007).

In the 1990s, Poland began to receive foreign investments and aid funds, among which it is worth stressing the importance of means for regional development. The role of these funds increased further after Poland's accession to the European Union, in 2004. In the space of the last 10 years, Poland has seen the process of population concentration and the dynamic growth of the largest urban agglomerations; there has been an improvement in the condition and provision of technical infrastructure elements while the role of industry in the national economy has waned. Additionally, a number of strategic documents shaping the country's spatial development have been adopted (Bański 2007).

\section{Study area, data collection and methods}

The aim of this article is to evaluate the intensity and directions of changes in land cover in Poland between 1990 and 2012. It was conducted on the basis of the CLC database. The essence of the programme is to provide information concerning land cover across the whole of Europe in a regular cycle and indicate the changes which take place between subsequent cycles. Poland has taken part in the implementation of all CORINE projects so far (Eowicki 2008). The authors have tested the hypothesis: "Between 1990 and 2012 changes of land cover in Poland had a different intensity. The greatest transformations concerned agriculture areas."

Forms of land cover distinguished in the program were organized hierarchically on three levels. The first one comprises 5 main categories of land cover, such as 
artificial surfaces, agricultural areas, wooded and semi-natural areas as well as wetland and aquatic areas. The second level includes 15 forms of land cover which may be presented on maps in scales from 1:500,000 to 1:1,000,000. The third level consists of 44 forms, of which 31 classes can be found in Poland. Satellite pictures served as a source of data used to elaborate these databases. In the methodology, only surface data with a minimum area of 25 ha and a width of at least $100 \mathrm{~m}$ are stored in the CLC database were adopted. The CLC database registers actual changes with a minimum area of 5 ha and a width of at least $100 \mathrm{~m}$ (Edman et al. 2011; Rujoiu-Mare, Mihai 2016). The CLC databases from 1990 and 2012 lay the foundation to conduct essential analyses for the purposes of this research. Comparing these four sets of data allowed us to confirm the changes which took place in the land usage in Poland after 1990. The relationship between each of the CLC data levels and their use in this article should be explained here. The analysis concerns all land cover transformations in Poland between 1990-2012. In order to maintain the highest level of accuracy, the study has examined whether there were any changes in the most detailed level of CLC and what their extent was. However, for the sake of maintaining clarity, the results are presented for the first level of data (Tables 1, 2, 3). Therefore, there is a situation where the table indicates changes in land coverage within the highest level of CLC.

GIS tools were used in order to specify changes in the form of land cover in Poland (Iverson 1988; Wear, Bolstad 1998; Van Doorn, Bakker 2007; Rujoiu-Mare, Mihai 2016). The authors calculated the surface and pointed to the distribution of areas which were subject to changes in the form of land cover over the period of 1990-2012. It was possible to capture all the changes which took place on any of the three levels of the CORINE database (Pasca, Nasui 2016; Schaffert, Steensen 2017). Firstly, the area (ha) and the percentage of changes for individual forms of land cover between 1990-2012 were determined, both at the national level and province by province (Tables 2,3 ). This made it possible to determine the intensity of changes at national and regional level. For this purpose, land cover data from 1990 and 2012 were used. The analyses were carried out for the first data level in the CLC database, where 5 forms of land cover were distinguished. The surface areas of these forms of land cover were calculated for both Poland as a whole and on a province-by-province basis from both 1990 and 2012. Then, data from the initial period was subtracted from the data from the end period, thus obtaining the area of changes. However, it should be emphasised that this method of calculation only showed changes that occurred in the overall balance of the land cover.

After this, a matrix of changes between forms of land cover in Poland between 1990 and 2012 was created (Grecchi et al. 2014, Sluis et al. 2016). The results were presented both in absolute values (ha) as well as in percentages referring to the total surface of the area subject to changes in the form of land cover in this period (Edman et al. 2011). It was thus determined in what direction the changes were 
occurring (Table 3). The indicated changes within one form of land cover (e.g. changes from one agricultural land usage into another) mean that there were transformations of land cover at some of the further levels distinguished in CORINE between 1990 and 2012. For example, there was a situation where there was an orchard in a given area in 1990, while in 2012 the same area was given over to another agricultural usage, with significant areas of natural vegetation. The change clearly happened, but only within a single (the first) level of CORINE. The above changes were determined by the imposition of two polygon layers in vector format. The first included land cover in 1990, the second in 2012. By 'intersecting' the layers, a terrain mosaic was obtained, with attributes of CORINE code from 1990 and 2012. Each of the areas with matching codes was a changed area. It was further possible to determine the direction of change and the area that this change covered. The matrix should be interpreted as follows. Cells at the intersections of lines ( 1 through 5 ) and columns (A through F) show values for changes in land cover within a given form in 1990 relative to the state in 2012. For example: cell 2A says that 781,600.9 ha of farmland in 1990 became anthropogenic in 2012. In addition, the value in the brackets shows that these changes account for $18.7 \%$ of all surface area of land cover change that occurred within the period in question. Column $\mathrm{F}$ includes the cumulative values for the changes in various forms of use in 1990. For example: cell $5 F$ says that $83,008.0$ ha of water areas in 1990 were transformed into land cover forms by 2012, and the changes account for less than $2 \%$ of the area of all changes in the period in question. The table was created (Table 3, Grecchi et al. 2014; Sluis et al. 2016) for changes between forms of land use in Poland between 1990 and 2012. Data are presented both in absolute terms (ha) as well as in percentages referring to the total area affected by land cover changes (Edman et al. 2011). Calculations in Table 3 do not indicate changes in the balance of land cover (see Tables 1 and 2), but the direction of change. Moreover, the changes in land cover may have occurred in different parts of the areas in question (which was not included in Tables 1 and 2). Therefore, the results obtained from these two different approaches do not overlap. For example, if there was an increase in agricultural area by 100 ha in one part of the province, but a decrease of 100 ha in another, Tables 1 and 2 will show that the general balance remained unchanged, despite there actually being changes in land cover (included in Table 3). This means that the application of these two calculation methods is justified in order to achieve the objective.

The following research algorithm was used to determine the area of municipalities that changed the form of land cover to anthropogenic. Initially, the total area of a municipality where land cover was transformed between 1990 and 2012 was calculated. This value means $100 \%$ of change for a given administrative unit. Then, only those that have been transformed into anthropogenic areas were selected from the whole set of areas. The last step involved the determination of the share 
of transformations that led to anthropogenic land cover form in 2012 in the total area of changes. The reverse changes were determined as follows. First, the total area where land cover changes occurred in areas that were anthropogenic in 1990 was calculated for each municipality. This value constituted $100 \%$ of the changes examined in this approach. Subsequently, only the transformed areas where land cover was not anthropogenic in 2012 were determined. Finally, their share in the above-mentioned total changes to anthropogenic areas was determined. At the third stage of the analysis of changes in land cover, attention shifted exclusively to those fluctuations which concerned artificial surfaces. The primary field was introduced to the research in the form of the cadastral unit (there are 3,126 such units in Poland) so as to enable a more precise analysis. It should be explained here that the subsequent stages of the research were conducted for municipalities, as Polish statistics at the central level (the Local Data Bank of the Main Statistical Office) do not have data aggregated to the level of the cadastral unit. For each out of 3,126 cadastral units the authors calculated the share in land surface which changed the form of land cover to artificial surfaces between 1990 and 2012, and then they also calculated the share of land which ceased to be used as artificial surfaces during the same period of time.

Then the authors assessed the spatial differentiation of the share of changes in land cover of individual municipalities in Poland in the analyzed period. To achieve this the authors used the Getis-Ord statistics. The Getis-Ord G statistic quantifies the relationship between two locations as the product of the values at the locations. G statistics present a local clustering test that is based on the concentration of values in the neighborhood of a unit.

Getis-Ord local statistic is given as:

$$
G_{i}^{*}=\frac{\sum_{j=1}^{n} w_{i, j} x_{j}-\bar{X} \sum_{j=1}^{n} w_{i, j}}{S \sqrt{\frac{\left[n \sum_{j=1}^{n} w_{i, j}^{2}-\left(\sum_{j=1}^{n} w_{i, j}\right)^{2}\right]}{n-1}}}
$$

where: is the attribute value for feature; is the spatial weight between feature and, is equal to the number of features and:

$$
\begin{gathered}
\bar{X}=\frac{\sum_{j=1}^{n} x_{j}}{n} \\
S=\sqrt{\frac{\sum_{j=1}^{n} x_{j}^{2}}{n}-(\bar{X})^{2}}
\end{gathered}
$$

Thanks to the method used it was possible to indicate concentration areas of the analyzed feature in constituent parts of the research area and its immediate vicinity. High positive values of the Getis-Ord statistics denote that high values of 
the researched feature (higher than the average) are concentrated on the area of the given constituent part and its adjacent areas (hot spots). High negative values of the statistics point to a concentration of relatively low values of the analyzed feature (lower than the average) on the area of the given constituent part as well as its adjacent areas (cold spots). Results close to zero denote a lack of visible spatial concentration (not significant; Ord, Getis 1995, 2001).

\section{Results and discussion}

In the years 1990-2012 in Poland there were changes to $9.5 \%$ of land cover, the most significant ones happening in agricultural areas $-49.62 \%$ of the total change. This was followed by artificial surface ( $24.78 \%$ of total change), then forest and semi natural areas (24.12\%). In all provinces, the surface of agricultural areas decreased, with the biggest (absolute) changes seen in mazowieckie and dolnośląskie (Tables 1 and 2). On the other hand, artificial surfaces have increased in all provinces, with the most intense changes (in ha) again seen in mazowieckie and dolnośląskie. For many years, both the mazowieckie (due to the presence of the metropolitan area of Warsaw) and dolnośląskie provinces have been viewed as two of the most attractive areas in Poland in terms of investments. This has been confirmed, among others, by research conducted by the Institute of Enterprise (Godlewska-Majkowska 2008).

It should also be emphasised that, apart from agricultural areas, wetlands also decreased by $6,483.43$ ha in Poland. Whereas, an increase could be seen in other forms of land cover, such as forest and semi natural areas and waterbodies. The growth of waterbodies (though not very large in the total changes in the period in question in Poland) is a beneficial phenomenon, as it contributes to the water balance of the landscape (Feranec et al. 2010).

When analysing individual provinces, it should be stated that the greatest changes took place in mazowieckie (accounting for approx. $13 \%$ of all changes in the period considered). In second place in this respect was the dolnośląskie province. In the case of mazowieckie province, approx. 194,945.65 ha of agricultural area disappeared, whereas artificial surfaces and forest, semi-natural areas, as well as waterbodies, grew by $93,908.82 \mathrm{ha}, 98,876.12$ ha and 2,126.72 ha, respectively. The changes were similar in dolnośląskie province. Artificial forests, forest and semi natural areas as well as waterbodies grew, by 77,134.87 ha, 46,818.64 ha, 1,223.74 ha, respectively, while the agricultural land and wetlands shrank by $123,913.44$ ha and 1,223.74 ha, respectively.

It should be noted that such changes, i.e. the increase in developed and forest areas at the expense of agricultural areas, can be seen more regularly in Poland. According to the provisions of the Act on the Protection of Agricultural and Forest 
Table 1 - The area of changes in forms of land cover in Poland in the years 1990-2012 by province

\begin{tabular}{|c|c|c|c|c|c|c|}
\hline \multirow[t]{2}{*}{ Province } & \multicolumn{6}{|c|}{ Changes in ha* } \\
\hline & $\begin{array}{l}\text { Artificial } \\
\text { surfaces }\end{array}$ & $\begin{array}{l}\text { Agricultural } \\
\text { areas }\end{array}$ & $\begin{array}{l}\text { Forest and } \\
\text { semi natural } \\
\text { area }\end{array}$ & Wetlands & Waterbodies & $\begin{array}{l}\text { Total change } \\
\text { in provinces }\end{array}$ \\
\hline Dolnośląskie & $77,134.87$ & $-123,913.0$ & $46,818.64$ & $-1,263.810$ & $1,223.744$ & $250,354.509$ \\
\hline Kujawsko-pomorskie & $25,694.81$ & $-50,990.4$ & $23,433.47$ & $1,231.563$ & 630.563 & $101,980.828$ \\
\hline Łódzkie & $62,016.26$ & $-98,097.8$ & $36,043.21$ & $-2,599.280$ & $2,637.635$ & $201,394.226$ \\
\hline Lubelskie & $51,898.25$ & $-113,125.0$ & $59,132.24$ & -600.729 & $2,695.589$ & $227,452.157$ \\
\hline Lubuskie & $25,254.42$ & $-53,385.1$ & $27,602.71$ & 162.833 & 365.184 & $106,770.300$ \\
\hline Małopolskie & $57,076.77$ & $-107,107.0$ & $46,896.77$ & -108.199 & $3,238.625$ & $214,427.208$ \\
\hline Mazowieckie & $93,908.82$ & $-194,946.0$ & $98,876.12$ & 33.975 & $2,126.723$ & $389,891.287$ \\
\hline Opolskie & $10,737.89$ & $-24,356.3$ & $12,477.45$ & -460.504 & $1,601.449$ & $49,633.578$ \\
\hline Podkarpackie & $48,920.59$ & $-120,994.0$ & $70,962.69$ & -447.893 & $1,557.889$ & $242,882.567$ \\
\hline Podlaskie & $32,285.06$ & $-60,746.2$ & $32,261.95$ & $-4,216.640$ & 415.799 & $129,925.619$ \\
\hline Pomorskie & $37,029.54$ & $-73,951.8$ & $36,435.08$ & -374.678 & 861.831 & $148,652.899$ \\
\hline Śląskie & $43,089.56$ & $-80,670.8$ & $35,427.00$ & -697.087 & $2,851.259$ & $162,735.745$ \\
\hline Świętokrzyskie & $41,660.18$ & $-84,573.4$ & $41,977.28$ & -92.680 & $1,028.574$ & $169,332.071$ \\
\hline Warmińsko-mazurskie & $30,480.20$ & $-101,352.0$ & $66,508.11$ & $3,113.028$ & $1,250.324$ & $202,703.339$ \\
\hline Wielkopolskie & $64,291.97$ & $-101,663.0$ & $34,265.71$ & -471.237 & $3,576.428$ & $204,268.196$ \\
\hline Zachodniopomorskie & $33,108.87$ & $-80,665.2$ & $45,829.24$ & 307.917 & 1419.190 & $161,330.409$ \\
\hline $\begin{array}{l}\text { The total surface area of } \\
\text { each form of land cover }\end{array}$ & $73,4588,1$ & $1,470,536.0$ & $714,947.70$ & $16,182.060$ & $27,480.810$ & $2,963,734.936$ \\
\hline $\begin{array}{l}\text { decrease }(-) \text { or increase }(+) \\
\text { of each form of land cover }\end{array}$ & $73,4588,1$ & $-1,470,536.0$ & $714,947.70$ & $-6,483.430$ & $27,480.810$ & \\
\hline
\end{tabular}

Source: own elaboration on the basis of CORINE data. Note: * "-" means decrease.

Land, non-agricultural and non-forest purposes should be allocated only to nonproductive areas, and in the absence thereof, those with the lowest usefulness for agriculture. However, due to the steady growth of developed areas, the surface of optimal development areas is shrinking. As a result, we observe the process of displacement of the agricultural function through housing, service or industrial development. In addition, changes were made to the Law on the Protection of Agricultural and Forest Land in 2008 (the Act came into force in 2009), which resulted in the abolition of the obligation to obtain permission to change land use for non-agricultural and non-forest purposes within cities (Prus 2012).

While analysing the percentage of changes in particular provinces, the situation looks somewhat different. The most intense process of urbanisation (manifested by the growth of artificial surfaces (Feranec et al. 2010)) was recorded in the following provinces: dolnośląskie (3.87\% of its area), małopolskie - 3.77\%, świętokrzyskie - $3.57 \%$, śląskie - $3.5 \%$ and łódzkie - $3.41 \%$. In turn, a particularly low percentage of urbanisation in the total area of provinces was observed in the following regions: 
opolskie $-1.14 \%$, warmińsko-mazurskie $-1.26 \%$, kujawsko-pomorskie $-1.43 \%$, zachodniopomorskie $-1.45 \%$.

In the case of agricultural areas, as mentioned above, there was a decrease in each province, with the biggest percentage of loss in świętokrzyskie $-7.25 \%$ and małopolskie $-7.09 \%$ and they decreased the least (compared to the total area of the provinces) in opolskie $-2.59 \%$ and kujawsko-pomorskie - $2.84 \%$ (Table 2). As noted by B. Prus (2012), the greatest number of conversions from agricultural lands are happening in rural and rural-urban municipalities, as these municipalities change their agricultural character and switch to multi-functional development.

Subsequently, forest and semi natural areas were also analysed. In analysing the studied regions, the largest percentage increase in relation to their total area was seen in podkarpackie $-3.96 \%$, świętokrzyskie $-3.6 \%$ and małopolskie $-3.1 \%$. In other regions, it was below $3 \%$ of their area (Table 2). The increase in the forest cover of the country is a visible result of the implementation of the National Program for Extending Forest Cover (KPZL) adopted in 1995. It intended that Poland would increase its forest cover to $30 \%$ in 2020 and to $33 \%$ in 2050. As noted by

Table 2 - The percentage of changes in forms of land cover in Poland in the years 1990-2012 by province

\begin{tabular}{|c|c|c|c|c|c|c|}
\hline \multirow[t]{2}{*}{ Province } & \multicolumn{5}{|c|}{ Percentage of changes by province } & \multirow{2}{*}{$\begin{array}{l}\text { Total } \\
\text { percentage } \\
\text { of changes } \\
\text { by province }\end{array}$} \\
\hline & $\begin{array}{l}\text { Artificial } \\
\text { surfaces }\end{array}$ & $\begin{array}{c}\text { Agricultural } \\
\text { areas }\end{array}$ & $\begin{array}{l}\text { Forest and } \\
\text { semi natural } \\
\text { areas }\end{array}$ & Wetlands & Waterbodies & \\
\hline Dolnośląskie & 3.87 & -6.22 & 2.35 & -0.06 & 0.06 & 12.56 \\
\hline Kujawsko-pomorskie & 1.43 & -2.84 & 1.31 & 0.07 & 0.04 & 5.68 \\
\hline Łódzkie & 3.41 & -5.39 & 1.98 & -0.14 & 0.14 & 11.07 \\
\hline Lubelskie & 2.07 & -4.50 & 2.35 & -0.02 & 0.11 & 9.05 \\
\hline Lubuskie & 1.81 & -3.82 & 1.97 & 0.01 & 0.03 & 7.64 \\
\hline Małopolskie & 3.78 & -7.09 & 3.10 & -0.01 & 0.21 & 14.19 \\
\hline Mazowieckie & 2.64 & -5.48 & 2.78 & 0.00 & 0.06 & 10.96 \\
\hline Opolskie & 1.14 & -2.59 & 1.33 & -0.05 & 0.17 & 5.28 \\
\hline Podkarpackie & 2.73 & -6.75 & 3.96 & -0.02 & 0.09 & 13.55 \\
\hline Podlaskie & 1.60 & -3.01 & 1.60 & -0.21 & 0.02 & 6.44 \\
\hline Pomorskie & 2.03 & -4.05 & 1.99 & -0.02 & 0.05 & 8.13 \\
\hline Śląskie & 3.51 & -6.57 & 2.89 & -0.06 & 0.23 & 13.26 \\
\hline Świętokrzyskie & 3.57 & -7.25 & 3.60 & -0.01 & 0.09 & 14.52 \\
\hline Warmińsko-mazurskie & 1.26 & -4.19 & 2.75 & 0.13 & 0.05 & 8.38 \\
\hline Wielkopolskie & 2.16 & -3.41 & 1.15 & -0.02 & 0.12 & 6.85 \\
\hline Zachodniopomorskie & 1.45 & -3.52 & 2.00 & 0.01 & 0.06 & 7.05 \\
\hline $\begin{array}{l}\text { The percentage of each } \\
\text { form of land cover change } \\
\text { in a total area of changes }\end{array}$ & 24.79 & 49.62 & 24.12 & 0.55 & 0.93 & \\
\hline
\end{tabular}

Source: own elaboration on the basis of CORINE data. 
A. Kaliszewski et al. (2014), the growth of forest areas results mainly from afforestation on non-state land within the framework of the EU Rural Development Program.

In the case of wetlands, in four regions their surface area was increased - lubuskie, zachodniopomorskie, kujawsko-pomorskie and warmińsko-mazurskie. In the mazowieckie province their surface area remained unchanged, while the remaining regions saw a decrease (Table 2).

It must be objectively stated that in the past decade the status of wetlands underwent considerable improvement compared to earlier post-war periods. In the 1950s, the idea of using peat for energy purposes was promoted, while between the 1960 s and 1980s there were large-scale wetland draining projects not supported by any economic, let alone environmental, calculations. In 2000, the National System of Protected Areas included about $3,500 \mathrm{~km}^{2}$ of wetlands, which constituted approx. $8 \%$ of the total area of hydrogenic habitats. $0.9 \%$ of the area of these habitats, including $2 \%$ of the total area of peat bogs were protected. The improvement of the situation was mainly determined by the ratification by Poland of international conventions of vital importance to wetlands. European Union regulations concerning agricultural land have great practical significance for wetlands. They impose the obligation to implement agri-environmental and afforestation programs in member and pre-accession states. The agri-environment programmes implemented in Poland protect primarily those wetlands still owned by farmers. These documents are: Council Regulation (EC) No. 1257/1999 of 17 May 1999 on rural development support and Council Regulation (EC) No. 1750/1999 of 23 July 1999 laying down detailed rules for the application of that regulation. Nevertheless, the most serious threats to the natural values of Polish wetlands and former wetlands are: unnecessary and excessive drainage ill-adapted to current agricultural needs; the development of flood protection in the form of river embankments, deepening of riverbeds and deforestation of riverbanks; the introduction of invasive vegetation into wetlands and swamps that have been universally abandoned by farmers; the 'farmerisation' of farms and the consolidation of land as a result of direct subsidies to agricultural production; afforestation of abandoned meadows without taking into account the needs of biodiversity (Dembek 2002).

The last form of land cover under analysis is waterbodies. In this case, changes between 1990 and 2012 within individual provinces ranged from $0.02 \%$ (podlaskie) to $0.23 \%$ (śląskie) (Table 2). After 1990, anthropogenic water reservoirs started appearing in Poland. The increase in their number in the śląskie province is mainly the result of the creation of post-mining reservoirs, while in małopolskie it was largely caused by the creation of retention reservoirs with permanent flood reserve (Ecophysiographic study 2015; Project of the change 2017).

In the last 10-15 years, there has been a sharp decline in the demand for sand for backfilling mining excavations in coal mines. This process may bring us closer to the 
end of more than 100 years of open-cast mining of backfill sand in the Upper Silesian Coal Basin (śląskie province). The 4 sand fields that are currently exploited have simple hydrogeologic conditions. Despite many anthropogenic threats, more than $90 \%$ of the water entering the mining excavations has the chemical composition of ordinary water. Preliminary forecasts mainly propose forest and water recultivation of mining excavations (Kropka, Wróbel 2001). The old post-glacial terrain and the wide anthropogenisation of water systems determine the negligible occurrence of natural reservoirs in Silesian Highlands. The few examples of inventoried lakes only relate to water bodies in natural wells. As noted by M. Rzętała (2000), there are bodies of water in non-flowing wells, mainly supplied by atmospheric water and shallow groundwater. We can see a large number of similar artificial bodies of water located in naturally occurring basins exploited by humans. A good example in this regard are - often described (e.g. Wach 1991; Dwucet, Krajewski, Wach 1992) sediment hollows (Jankowski, Molenda, Rzękała 2007).

Analysis of changes in land cover between 1990 and 2012 conducted for Poland showed that agricultural areas underwent changes most often. They were converted mainly into other agricultural land types (41.5\%), artificial surfaces $(18.7 \%)$, forests as well as semi-natural ecosystems (18.6\%; Table 3$)$. This is, among other things, a consequence of Poland's accession to the European Union and adoption of its development policy. The areas of the most unfavourable natural conditions, where agricultural production is not cost-effective, were mainly excluded from agricultural use (Bański 1998). In addition, there were considerable changes in the forest areas in the analyzed period (14.9\%).

Table 3 - Changes in the forms of land cover in Poland between 1990 and 2012

\begin{tabular}{|c|c|c|c|c|c|c|c|}
\hline & \multirow[t]{4}{*}{ Form of use in 1990} & \multicolumn{6}{|c|}{ Area of change in ha (share in total area of change in \%) } \\
\hline & & \multicolumn{6}{|c|}{ Form of use in 2012} \\
\hline & & A & B & C & D & $\mathrm{E}$ & $\mathrm{F}$ \\
\hline & & $\begin{array}{l}\text { Artificial } \\
\text { surfaces }\end{array}$ & $\begin{array}{l}\text { Agricultural } \\
\text { areas }\end{array}$ & $\begin{array}{l}\text { Forest and } \\
\text { semi natural } \\
\text { areas }\end{array}$ & Wetlands & Waterbodies & Total \\
\hline 1 & Artificial surfaces & $\begin{array}{r}51,435.7 \\
(1.2)\end{array}$ & $\begin{array}{r}45,001.4 \\
(1.1)\end{array}$ & $\begin{array}{r}20,090.4 \\
(0.5)\end{array}$ & $\begin{array}{r}140.3 \\
(0.0)\end{array}$ & $\begin{array}{r}3,008.0 \\
(0.1)\end{array}$ & $\begin{array}{r}119,675.9 \\
(2.9)\end{array}$ \\
\hline 2 & Agricultural areas & $\begin{array}{r}781,600.9 \\
(18.7)\end{array}$ & $\begin{array}{r}1,732,276.6 \\
(41.5)\end{array}$ & $\begin{array}{r}775,369.5 \\
(18.6)\end{array}$ & $\begin{array}{r}11,150.3 \\
(0.3)\end{array}$ & $\begin{array}{r}21,283.8 \\
(0,5)\end{array}$ & $\begin{array}{r}3,321,681.3 \\
(79.6)\end{array}$ \\
\hline 3 & $\begin{array}{l}\text { Forest and semi } \\
\text { natural areas }\end{array}$ & $\begin{array}{r}21,761.1 \\
(0.5)\end{array}$ & $\begin{array}{r}57,346.8 \\
(1.4)\end{array}$ & $\begin{array}{r}535,462.2 \\
(12.8)\end{array}$ & $\begin{array}{r}4,865.9 \\
(0.1)\end{array}$ & $\begin{array}{r}5,550.8 \\
(0.1)\end{array}$ & $\begin{array}{r}624,987.0 \\
(14.9)\end{array}$ \\
\hline 4 & Wetlands & $\begin{array}{r}451.4 \\
(0.0)\end{array}$ & $\begin{array}{r}7,640.2 \\
(0.2)\end{array}$ & $\begin{array}{r}10,859.4 \\
(0.3)\end{array}$ & $\begin{array}{r}1,246.4 \\
(0.0)\end{array}$ & $\begin{array}{r}3,958.4 \\
(0.1)\end{array}$ & $\begin{array}{r}24,155.9 \\
(0.6)\end{array}$ \\
\hline 5 & Waterbodies & $\begin{array}{r}1,027.4 \\
(0.0)\end{array}$ & $\begin{array}{r}2,635.4 \\
(0.1)\end{array}$ & $\begin{array}{r}2,004.9 \\
(0.0)\end{array}$ & $\begin{array}{r}610.4 \\
(0.0)\end{array}$ & $\begin{array}{r}76,729.8 \\
(1.8)\end{array}$ & $\begin{array}{r}83,008.0 \\
(1.9)\end{array}$ \\
\hline
\end{tabular}




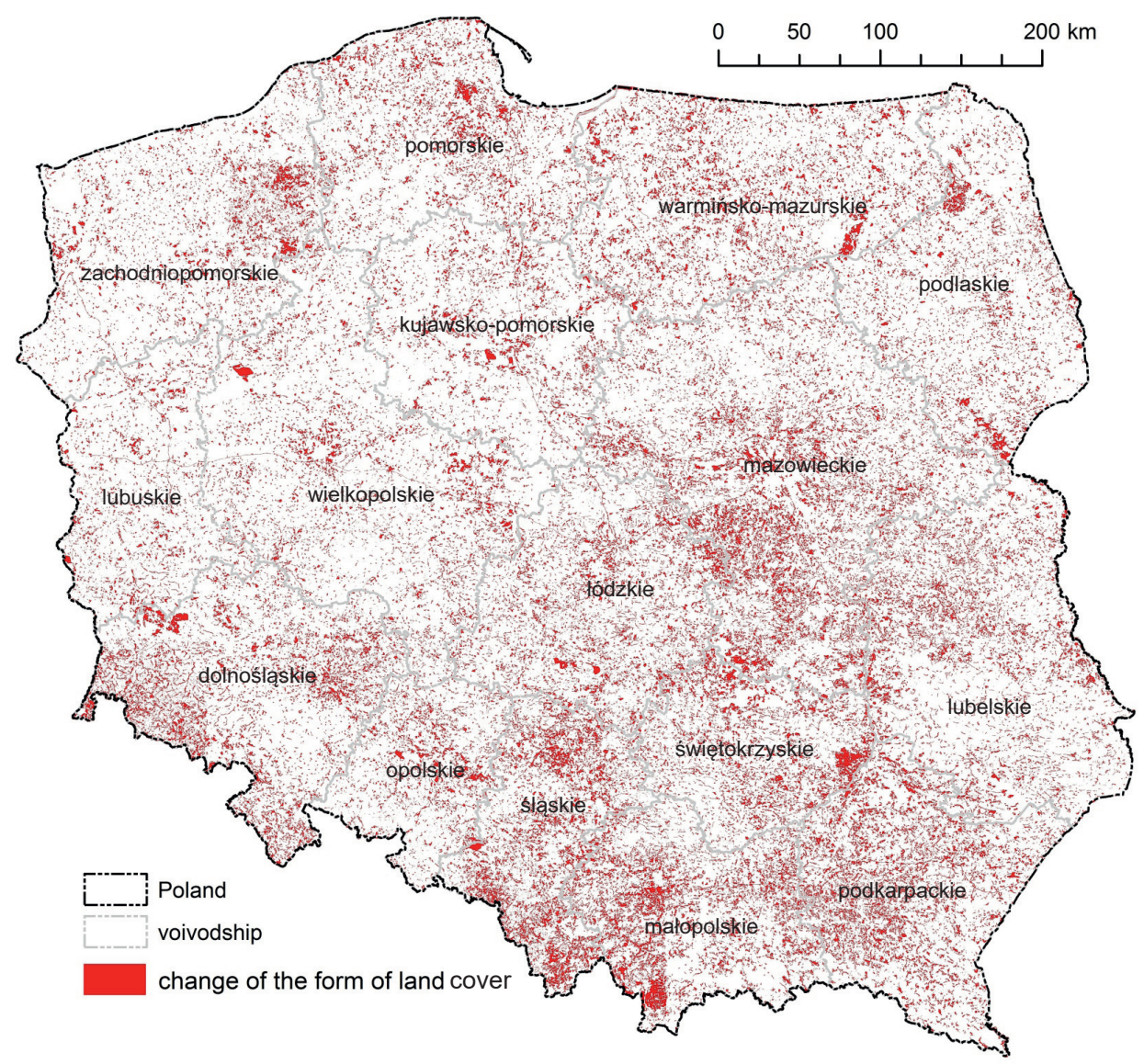

Fig. 1 - Changes in the forms of land cover in Poland between 1990 and 2012. Source: own elaboration on the basis of CORINE data.

Analyzing the whole period between 1990 and 2012 it should be noted that it was the mazowieckie province that was affected most as far as the surface is concerned ( $12.7 \%$ of all changes). It was followed by the provinces of dolnośląskie, podkarpackie, małopolskie and lubelskie (about 7\% each of all changes in land cover in Poland; Fig. 1). Changes in land cover referred mostly to agricultural areas as well as wooded and semi-natural areas in all analyzed periods.

At the following stage, the authors focused on changes in land cover connected with artificial surfaces (Fig. 2). These were presented in relative terms as a share in the total surface of individual municipalities in Poland. Spatial differentiation of the changes into areas converted by man (average for Poland $4.38 \%$ ) shows that they can be found most often in the southern part of the country, especially within big cities and their immediate vicinity. From this perspective the municipalities 

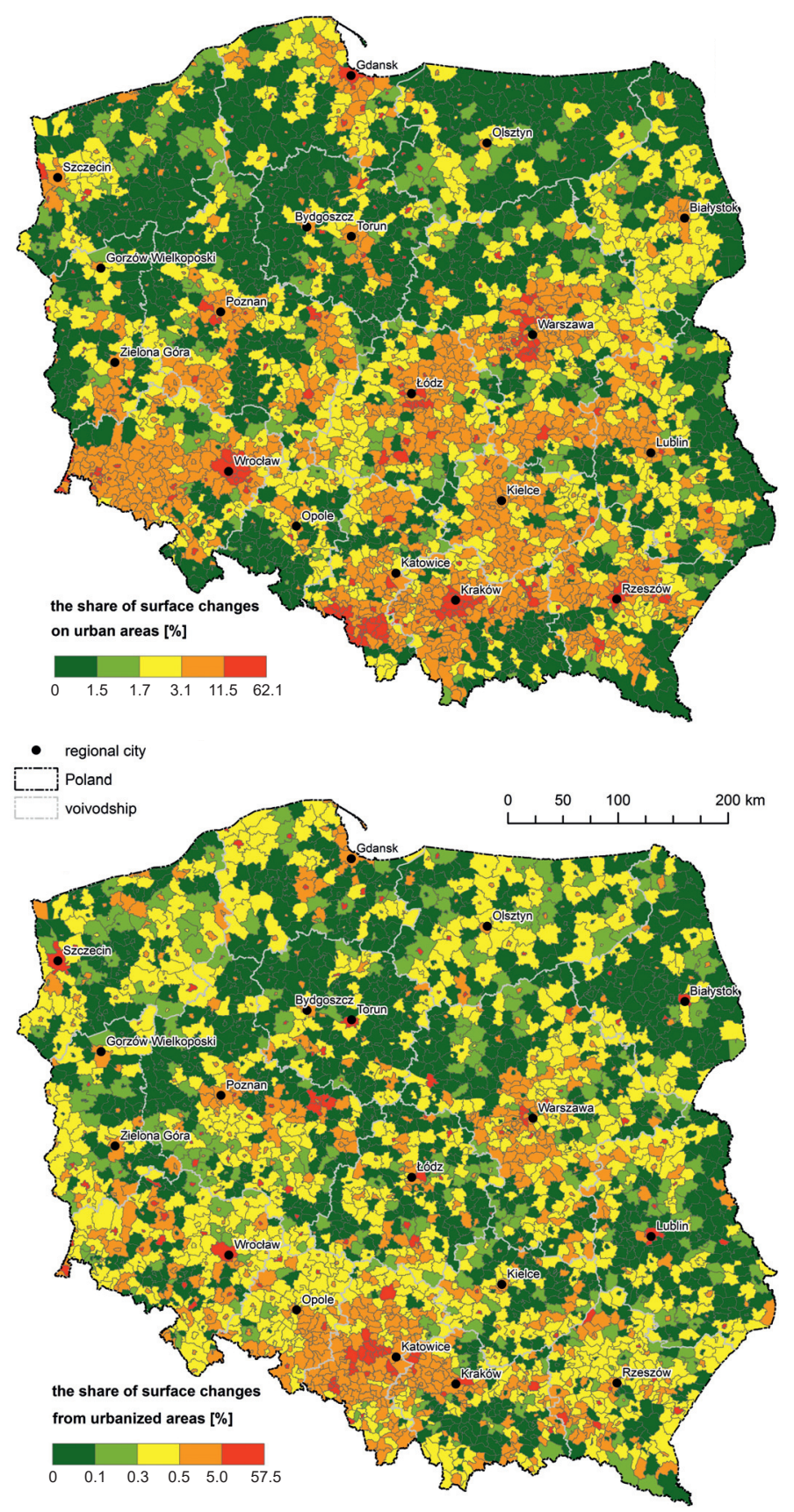

Fig. 2 - Change in the non-anthropogenic form of land cover into anthropogenic areas (top map) and from anthropogenic areas into non-anthropogenic (bottom map) in Poland between 1990 and 2012. Source: own elaboration on the basis of CORINE data. 
of the warmińsko-mazurskie region as well as that of zachodniopomorskie remain immune to the processes of antropopression to the largest degree. A reverse process took place between 1990 and 2012 in a far less intensive manner and concerned mostly the regions of Warsaw and dolnośląskie (average for Poland 0.90\%).

The biggest environmental pressure can thus be seen in two groups of municipalities - the most populous cities (Warsaw with its surrounding concentrates more than half of the demographic potential of the mazowieckie province) and the largest industrial centers (Śleszyński 2015).

Changes in land cover which occurred between 2000 and 2012 and resulted from transformations of the political system on the one hand, and Poland's accession to the EU on the other are, however, far more important with regard to the aim of this work (Fig. 3). The most intensive changes in this period took place in the mazowieckie province; they amounted to about $13 \%$ of all changes, and concerned mainly agricultural areas.

In the analyzed period there was a surge in artificial surfaces, which mainly referred to the areas located under the influence of big cities, such as Kraków, Wrocław or Warsaw. The observed process of suburbanization consisting in the expansion of the suburban zone is characteristic of Polish cities in the period in question (Węcławowicz et al. 2006; Czarnecki 2011).

Research carried out by means of measurements of concentrations showed a considerable disproportionality in the distribution of changes in land cover in Poland between 1990 and 2012 (Fig. 3). Concentrations of municipalities in which the greatest transformations in land cover took place in the analyzed period can be found in the provinces of ślaskie, małopolskie and podkarpackie. These are provinces which are characterized by considerable transformations of post-industrial areas. In recent years, Poland has seen the advent of companies specializing in taking over post-industrial areas and, later, preparing them for new land cover type.

Directions of these transformations concerned mainly a decrease in the surface of agricultural land at the gain of an increase in the share of wooded and artificial surfaces. Intensive transformations of agricultural land in Poland in the analyzed period were also confirmed by other research (Bański 1998, Nalej 2016). In turn, research by W. Dzun, W. Musiał (2013) shows that this process is slowest in provinces with favourable agrarian structure and high agricultural culture, i.e. in kujawsko-pomorskie, wielkopolskie and opolskie. It can be assumed that the EU's agricultural policy, as well as environmental policy and environmental protection, will be important elements in shaping future land use structure in Poland.

Unfortunately, it is to be expected that in the coming years this tendency to transform agricultural land (including that with the greatest agricultural value) into non-agricultural uses, especially within city limits, will be maintained, due to changes in the Act on the Protection of Agricultural and Forest Land (Act 2008), which no longer requires the consent of the Minister of Agriculture and 


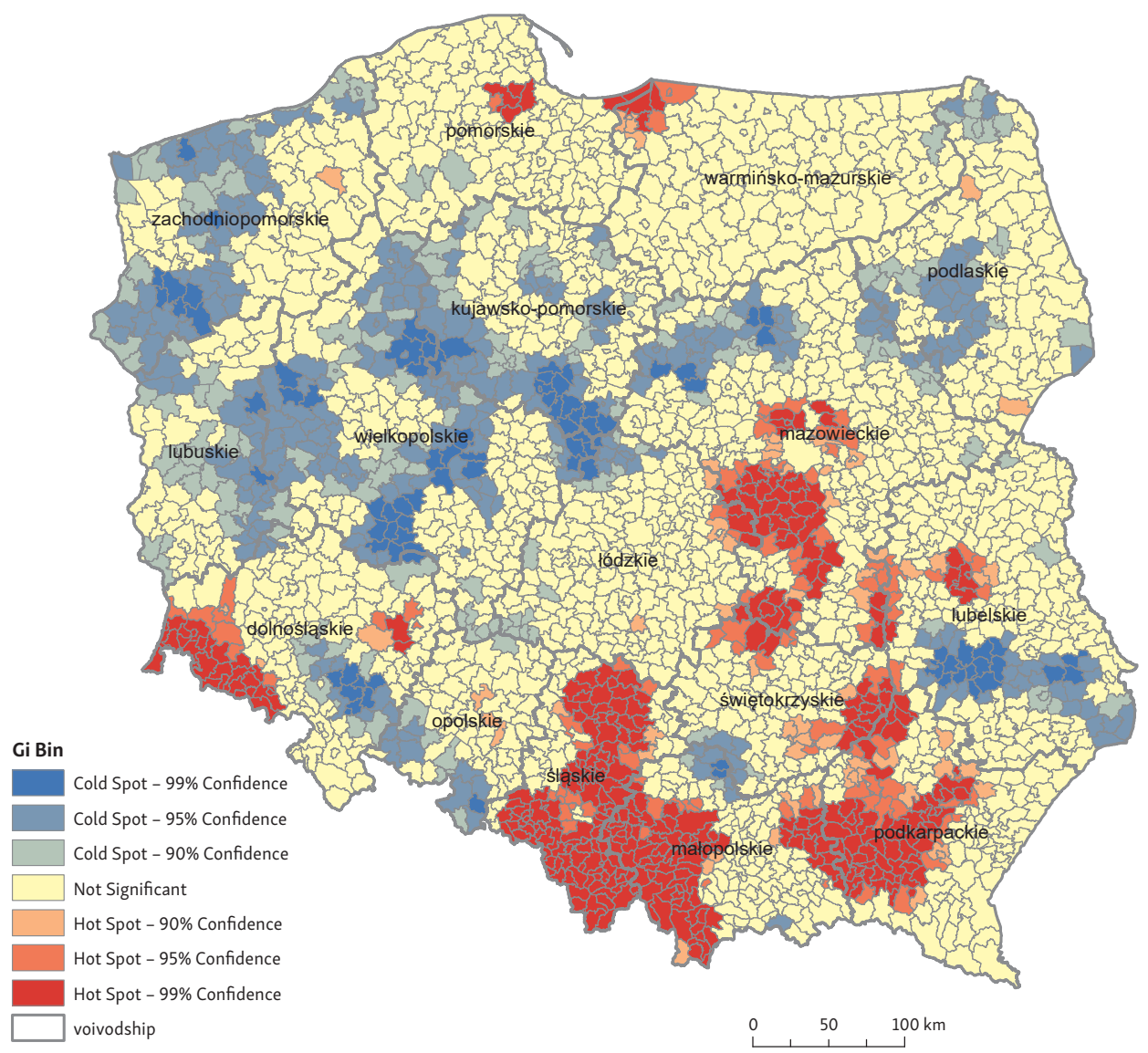

Fig. 3 - Hot spots and cold spots of percentage of land cover changes in Poland between 1990-2012. Source: own elaboration on the basis of the CORINE data.

Rural Development (Woch 2014; Woch, Woch 2014). It should also be emphasised that part of the transformation of land usage is related to the emergence of new instruments of the Common Agricultural Policy of the European Union. It is well known from the experience of the EU15 that these instruments can cause profound changes in land use, leading to increased monocultures in agriculture. Agri-environmental programmes and afforestation of agricultural land, included in the 2007-2013 Rural Development Plan (Rowiński 2008; Woch 2014; Woch, Woch 2014) are important for counteracting these unfavourable phenomena.

Analyses into changes in land cover are very important and may be used to create strategic documents with regard to spatial planning or spatial policy on the national, regional or even local level. The results obtained in this article may be extended to include qualitative research, mainly in those regions in which changes 
are most intensive, so as to discover how they affect the living conditions of inhabitants and whether the local policy is conducted in a way which best corresponds to beneficial local development. In addition, data on land cover may be used in research into spatial accessibility, in particular in cumulative analyses, which is an important and relatively popular application trend for this kind of spatial data. These methodologically-advanced analyses are often mostly based on traffic flow, which is variable and depends on a number of factors (Śleszyński 2015).

The conducted research shows that analysis can be done in an accessible way with the use of the latest topographic data, including models of land cover (here the CLC). Until recently, these means were not useful in modelling accessibility due to the insufficient degree of accuracy of maps. Nevertheless, progress made thanks to the technology of teledetection, combined with increasingly wider availability of these data, inspires hope for the arrival of new useful applications for the whole spectrum of scientific disciplines. Moreover, for many countries the CORINE database is the only database covering their whole area that is made according to uniform principles and systematically updated. It has a uniform methodology of data acquisition for practically the whole of Europe, which makes possible comparative studies (e.g. Feranec et al. 2000, 2006, 2007, 2012). This is of great importance, as changes in land use are inevitable and determined by the necessary development of urbanisation, transport, services and agricultural production. However, their dynamics and spatial location should be constantly monitored. This is a prerequisite for rational spatial management, based on a meaningful assessment of the direction and pace of change (Woch 2014).

\section{Conclusions}

Information on land use and coverage is very often used in contemporary scientific research. The conducted analyses allowed us to conclude that changes in land cover in Poland between 1990-2012 were very intensive and covered a considerable surface of the country. The authors have verified the hypothesis positively.

In Poland, in the years 1990-2012, changes in the form of land cover occurred, on average, over approx. 134,715 ha per year, i.e. approx. $0.43 \%$ of the total area (results from the general balance of land cover). In a significant part, these changes took place within agricultural land, but also included non-agricultural land, mainly artificial surfaces and forest, and semi-natural areas. Most changes (expressed in ha) happened in mazowieckie and dolnośląskie provinces. According to F. Woch (2014), in the years 1990-2000 changes in the form of land cover occurred in Poland over an area of approx. 25,500 ha annually, or approx. $0.08 \%$ of the total area, and in the years 2000-2006 these changes happened at a higher rate of approx. $0.1 \%$ of the total area per year. As is evident after 2006, the changes 
have significantly intensified, but the direction of these changes has not - they were still at the expense of agricultural land.

In the studied regions, the coverage of agricultural areas decreased systematically, especially in mazowieckie and dolnośląskie provinces. The loss of indicated areas was mainly for the benefit of artificial surfaces, forest, and semi natural areas. In turn, the smallest surface changes occurred in the opolskie province.

As a result of the increasing area of developed land, there is a significant shrinkage of valuable agricultural lands. Therefore, the issue of land protection should be a priority in Poland.

\section{References}

Act of $19^{\text {th }}$ December 2008 on the Protection of Agricultural and Forest Land, (Dz.U. z 2008 r. Nr 237, poz. 1657).

ALPHAN, H. (2003): Land-use change and urbanization of Adana, Turkey. Land Degradation \& Development, 14, 6, 575-586. https://doi.org/10.1002/ldr.581.

BAŃSKI, J. (1998): Gospodarka ziemią w Polsce w okresie restrukturyzacji. Warszawa: IGiPZ PAN, http://rcin.org.pl/Content/36221/WA51_45531_r1998_Gospodarka-ziemia.pdf (6.6.2017).

BAŃSKI, J. (2007): Koncepcje rozwoju struktury przestrzennej w Polsce - polaryzacja czy równoważenie? Przegląd Geograficzny, 79, 1, 45-77, http://geoplan.edu.pl/wp-content/ uploads/2015/11/1_Koncepcje_rozdo_SRU_woju.pdf (6.6.2017).

BERGERON, G., PENDER, J. (1999): Determinants of land cover change: evidence from a community study in Honduras. EPTD Discussion Paper, 46, http://www.ifpri.org/sites/default/ files/publications/eptdp46.pdf (6.6.2017).

BRIASSOULIS, H. (1991): Factors influencing land-use and land cover change. Land cover, Land Cover and Soil Sciences, 1, http://www.eolss.net/sample-chapters/c12/E1-05-01-03. $\operatorname{pdf}(6.6 .2017)$.

CEBECAUER, T., HOFIERKA, J. (2008): The consequences of land-cover changes on soil erosion distribution in Slovakia. Geomorphology, 98, 3, 187-198.

CZARNECKI, B. (2011): Przejawy i konsekwencje depopulacji polskich miast. Zarys problemu. Architecturae et Artibus, 3, 13-20, http://pbc.biaman.pl/Content/14556/Architektura\%20 -numer\%204\%20-\%202011-\%20do\%20druku.pdf (6.6.2017).

DĄBROWSKI, A. (2016): Metodyka opracowywania szczegółowych map pokrycia terenu na podstawie istniejących źródeł danych. In: Nowak, M. (ed.): GIS i dane przestrzenne w ocenach oddziaływania na środowisko, Podręcznik dobrych praktyk. Wydawnictwo Naukowe, Poznań, 167-182.

DEMBEK, W. (2002): Problemy ochrony i restytucji mokradeł w Polsce. Inżynieria Ekologiczna, $6,68-85$.

DU, J., THILL, J.C., PEISER, R.B., FENG, C. (2014): Urban land market and land-use changes in post-reform China: A case study of Beijing. Landscape and Urban Planning, 124, 118-128. https://doi.org/10.1016/j.landurbplan.2014.01.012.

DWUCET, K., KRAJEWSKI, W., WACH, J. (1992): Rekultywacja i rewaloryzacja środowiska przyrodniczego. Wydawnictwo Uniwersytetu Śląskiego, Katowice. 
DZUN, W., MUSIAE, W. (2013): Zagospodarowanie ziemi rolniczej w Polsce w okresie przed-i poakcesyjnym w ujęciu regionalnym. Wieś i Rolnictwo, 4, 161, 62-78.

EDMAN, T., ANGELSTAM, P., MIKUSIŃASKI, G., ROBERGE, J.M., SIKORA, A. (2011): Spatial planning for biodiversity conservation: Assessment of forest landscapes' conservation value using umbrella species requirements in Poland. Landscape and Urban Planning, 102, 1, 16-23, https://doi.org/10.1016/j.landurbplan.2011.03.004.

Ecophysiographic study to the Silesian Spatial Development Plan, 2015, Katowice.

FERANEC, J., HAZEU, G., CHRISTENSEN, S., JAFFRAIN, G. (2007): CORINE land cover change detection in Europe (case studies of the Netherlands and Slovakia). Land cover Policy, 24, 234-247.

FERANEC, J., JAFFRAIN, G., SOUKUP, T., HAZEU, G. (2010): Determining changes and flows in European landscapes 1990-2000 using CORINE land cover data. Applied Geography, 30, 19-35.

FERANEC, J., OTAHEL, J. (2001): Land cover of Slovakia. Bratislava (Veda), 122.

FERANEC, J., OTAHEL, J., CEBECAUER, T., MACHKOVA, N., NOVACEK, J. (2005): Land cover changes of Slovakia in the period 1990-2000. Schriften aus der Forstlichen Fakultät der Universität Göttingen und der Niedersächsischen Forstlichen Versuchsanstalt, 138, 139-147.

FERANEC, J., SOUKUP, T., HAZEU, G., JAFFRAIN, G. (2012): Land cover and its change in Europe: 1990-2006. In Giri, Ch. (Ed), Remote sensing of land cover and land cover. Principles and applications. CRC Press, Taylor \& Francis Group, Boca Raton, 285-301.

FERANEC, J., SOUKUP, T., HAZEU, G., JAFFRAIN, G., eds. (2016): European landscape dynamics: CORINE land cover data. CRC Press.

FERANEC, J., STOIMENOV, A., OTAHEL, J., VASTEVA, R., ROPECKA, M., BETAK, J., HUSAR, K. (2006): Changes of rural landscape in Slovakia and Bulgaria in 1990-2000 identified by application of CORINE land cover data (case studies - Trnava and Plovdiv region). In: Braun, M. (ed): EARSeL eProceedings of the Second Workshop of the EARSeL SIG on Remote Sensing of Land cover and Land Cover Application and Development. EARSeL and Universität, Bonn, 441-454.

FERANEC, J., ŠỦRI, M., OTAHEL, J., CEBECAUER, T., KOLA, J., SOUKUP, T., ZDENKOVA, D., WASZMUTH, J., VAJDEA, V., VIJDEA, A., NITICA, C. (2000): Inventory of major landscape changes in the Czech Republic, Hungary, Romania and Slovak Republic 1970s-1990s. International Journal of Applied Earth Observation and Geoinformation, 2, 129-139.

GODLEWSKA-MAJKOWSKA, H. (2008): Województwo mazowieckie na mapie atrakcyjności inwestycyjnej Polski. MAZOWSZE Studia Regionalne, 1, 47-62.

GRECCHI, R.C., GWYN, Q.H.J., BÉNIÉ, G.B., FORMAGGIO, A.R., FAHL, F.C. (2014): Land cover and land cover changes in the Brazilian Cerrado: A multidisciplinary approach to assess the impacts of agricultural expansion. Applied Geography, 55, 300-312, https://doi. org/10.1016/j.apgeog.2014.09.014.

GUTMAN, G., RADELOFF, V., eds. (2016): Land-cover and Land-use Changes in Eastern Europe After the Collapse of the Soviet Union in 1991. Springer.

HOUGHTON, R.A. (1994): The world-wide extent of land-use change. BioScience, 44, 5, 305-313, https://doi.org/10.2307/1312380.

IVERSON, L.R. (1988): Land-use changes in Illinois, USA: The influence of landscape attributes on current and historic land cover. Landscape Ecology, 2, 1, 45-61, https://doi.org/10.1007/ BF00138907.

JANKOWSKI, A., MOLENDA, T., RZĘTAŁA, M. (2001): Reservoirs in subsidence basins and depression hollows in the Silesian Upland - selected hydrological matters. Limnological Review, 1. 
KALISZEWSKI, A., WYSOCKA-FIJOREK, E., JABŁOŃSKI, M., MŁYNARSKI, W. (2014): Aktualizacja Krajowego Programu Zwiększania Lesistości 2014, Sękocin Stary: Instytut Badawczy Leśnictwa, Zakład Zarządzania Zasobami Lesnymi.

KOPKA, J., WRÓBEL, J. (2001): Przekształcenia warunków hydrogeologicznych w obszarach odkrywkowej eksploatacji piasków podsadzkowych w rejonie Górnośląskiego Zagłębia Węglowego, Przegląd Geologiczny, 49, 7, 631-638.

LI, L., WANG, Y. (2016): Land cover/Cover Change from 2001 to 2010 and its Socioeconomic Determinants in Guangdong Province, A Rapid Urbanization Area of China. Journal of Agricultural Sciences, 22, 275-294, http://tarimbilimleri.agri.ankara.edu.tr/2016/22_2/13. makale(1).pdf (6.6. 2017).

ŁOWICKI, D. (2008): Land cover changes in Poland during transformation. Case study of Wielkopolska region. Landscape and Urban Planning, 87, 4, 279-288, https://doi.org/10.1016/j. landurbplan.2008.06.010.

LU, D., MAUSEL, P., BRONDIZIO, E., MORAN, E. (2004): Change detection techniques. International journal of remote sensing, 25, 12, 2365-2401.

MEDLEY, K., OKEY, B. W., BARRET, G.W., LUCAS, M.F., RENWICK, W.H. (1995): Landscape change with agricultural intensification in a rural watershed, southwestern Ohio. USA. Landscape Ecology, 10, 3, 161-176, https://doi.org/10.1007/BF00133029.

MEIRICH, S. (2008): GSE Land - Mapping Guide for a European Urban Atlas, 1, 1-36.

MEYER, W.B., TURNER II, B.L. (1992): Human Population Growth and Global Land-Use/ Cover Change. Annual Review of Ecology and Systematics, 23, 39-61, http://www.jstor.org/ stable/2097281 (6.6.2017).

NALEJ, M. (2016): Agricultural land cover changes in metropolitan areas of Poland for the period 1990-2012. Miscellanea Geographica, 20, 2, 39-45, https://doi.org/10.1515/mgrsd-2016-0005.

NGUYEN, S.T. (2008): Determinants of land-use change: A case study from the lower Mekong delta of southern Vietnam. Electronic Green Journal, 1, 27, https://doi.org/10.5811/ westjem.2011.5.6700.

NGUYEN, T.T., NGUYEN, L.D., LIPPE, R.S., GROTE, U. (2016): Determinants of Farmers' Land cover Decision-Making: Comparative Evidence From Thailand and Vietnam. World Development, 89, 199-213, https://doi.org/10.1016/j.worlddev.2016.08.010.

ORD, J.K., GETIS, A. (2001): Testing for Local Spatial Autocorrelation in the Presence of Global Autocorrelation. Journal of Regional Science, 41, 3, 411-432.

ORD, J.K., GETIS, A. (1995): Local Spatial Autocorrelation Statistics: Distributional Issues and an Application. Geographical Analysis, 27, 286-306, https://doi.org/10.1111/j.1538-4632.1995. tb00912.x.

PASCA, A., NASUI, D. (2016): The use of Corine Land Cover 2012 and Urban Atlas 2012 databases in agricultural spatial analysis. Case study: Cluj county, Romania. Journal of Agricultural Sciences, 48, 4, 314-322, http://www.rjas.ro/download/paper_version.paper_file.94fa9a3e b85118dd.7061736361206164656c612e706466.pdf (6.6. 2017).

PIJANOWSKI, B.C., BROWN, D.G., SHELLITO, B.A., MANIK, G.A. (2002): Using neural networks and GIS to forecast land cover changes: A Land Transformation Model. Computers, Environment and Urban Systems, 26, 6, 553-575, https://doi.org/10.1016/S0198-9715(01)00015-1.

POPOVICI, E.A., BĂLTEANU, D., KUCSICSA, G. (2013): Assessment of changes in land-use and land-cover pattern in Romania using Corine Land Cover Database. Carpathian Journal of Earth and Environmental Sciences, 8, 4, 195-208.

PRASTACOS, P., CHRYSOULAKIS, N. (2011): Urban Atlas, land cover modelling and spatial metric techniques. European Regional Science Association. 
PRISHCHEPOV, A.V., MÜLLER, D., DUBININ, M., BAUMANN, M., RADELOFF, V.C. (2013): Land cover Policy Determinants of agricultural land abandonment in post-Soviet European Russia. Land cover Policy, 30, 873-884, https://doi.org/10.1016/j.landusepol.2012.06.011.

Project of the change of the Spatial Development Plan of the Malopolska Region, 2017, Department of Regional Policy, Marshal's Office of the Malopolska Region.

PRUS, B. (2012): Kierunki zmian przeznaczenia gruntów rolnych i leśnych w Polsce. Acta Scientiarum Polonorum. Geodesia et Descriptio Terrarum, 11, 2, 27-40, http://yadda.icm.edu. pl/yadda/element/bwmetal.element.baztech-article-BPBD-0004-0012/c/httpwww_aqua_ ar_wroc_plactaplfull42012000040201200011000020002700040.pdf (6.6. 2017).

ROWIŃSKI, J. (2008): Program Rozwoju Obszarów Wiejskich na lata 2007-2013. Instytut Ekonomiki Rolnictwa i Gospodarki Żywnościowej-Państwowy Instytut Badawczy.

RUJOIU-MARE, M.R., MIHAI, B.A. (2016): Mapping Land Cover Using Remote Sensing Data and GIS Techniques: A Case Study of Prahova Subcarpathians. Procedia Environmental Sciences, 32, 244-255.

RZĘTAŁA, M. (2000): Wybrane problemy eksploatacji i ochrony zbiorników wodnych na obszarze województwa śląskiego. In: Jankowski A.T., Myga-Piątek U., Ostaficzuk, S. (red.): Środowisko przyrodnicze regionu górnośląskiego - stan poznania, zagrożenia i ochrona, 117-131.

SALVATI, L., MUNAFO, M., MORELLI, V. G., SABBI, A. (2012): Low-density settlements and land cover changes in a Mediterranean urban region. Landscape and Urban Planning, 105, 1, 43-52, https://doi.org/10.1016/j.landurbplan.2011.11.020 (6. 6. 2017).

SCHAFFERT, M., STEENSEN, T. (2017): Land Cover Changes in Northern Germany Between 1990 and 2000 - An East-West Perspective. In E. Hepperle, R. Dixon-Gough, R. Mansberger, J. Paulsson, J. Hernik, T. Kalbro (eds.), 157-169.

ŚLESZYŃSKI, P. (2015): Expected traffic speed in Poland using Corine land cover, SRTM-3 and detailed population places data. Journal of Maps, 11, 2, 245-254, https://doi.org/10.1080/17 445647.2014.954645 (6.6.2017).

SLUIS, T. VAN DER, PEDROLI, B., KRISTENSEN, S.B.P., LAVINIA, G. (2016): Land cover Policy Changing land cover intensity in Europe - Recent processes in selected case studies. Land cover Policy, 57, 777-785. https://doi.org/10.1016/j.landusepol.2014.12.005.

STOEBNER, T.J., LANT, C.L. (2014): Geographic determinants of rural land covers and the agricultural margin in the Central United States. Applied Geography, 55, 138-154, https:// doi.org/10.1016/j.apgeog.2014.09.008 (6.6.2017).

VAN DOORN, A.M., BAKKER, M.M. (2007): The destination of arable land in a marginal agricultural landscape in South Portugal: An exploration of land cover change determinants. Landscape Ecology, 22, 7, 1073-1087. https://doi.org/10.1007/s10980-007-9093-7.

VESTERBY, M., HEIMLICH, R.E. (1991): Land cover and demographic change: results from fast-growing counties. Land Economics, 67, 3, 279-291, http://www.jstor.org/stable/3146423 (6.6. 2017).

WACH, J. (1991): Wpływ antropopresji na kształtowanie się rzeźby terenu województwa katowickiego. In: Jankowski, A.T., Szczypek, T. (red.): Materiały Sympozjum Polsko-Czeskiego 'Człowiek i środowisko w górnośląsko-ostrawskim regionieprzemysłowym', 115-119.

WEAR, D.N., BOLSTAD, P. (1998): Land-use changes in Southern Appalachian landscapes: Spatial analysis and forecast evaluation. Ecosystems, 1, 575-594, https://doi.org/10.1007/ s100219900052 (6.6.2017).

WĘCŁAWOWICZ, G., BAŃSKI, J., DEGÓRSKI, M., KOMORNICKI, T., KORCELLI, P., ŚLESZYŃSKI, P. (2006): Przestrzenne zagospodarowanie Polski na początku XXI wieku, http://fbc.pionier.net.pl/id/oai:rcin.org.pl:2270 (6.6. 2017). 
WENDT, J. (2001): The administrative division of Poland and the prospects of the transborder co-operation. Region and Regionalism, 5, 39-48, http://depot.ceon.pl/bitstream/handle/123456789/5459/The_administrative_division_of_Poland_and_the_prospects_of_the_ transborder_co-operation.pdf?sequence=1\&isAllowed=y (6.6. 2017).

WENDT, J. (2007): Wymiar przestrzenny struktur i aktywności społeczeństwa obywatelskiego w Polsce. Warszawa: Instytut Geografii i Przestrzennego Zagospodarowania im. Stanisława Leszczyckiego PAN, http://rcin.org.pl/Content/553/Wa51_3477_r2007-nr208_Prace-Geogr. $\operatorname{pdf}(6.6 .2017)$.

WICKHAM, J.D., STEHMAN, S.V., SMITH, J.H., YANG, L. (2004): Thematic accuracy of the 1992 national land-cover data for the western United States. Remote Sensing of Environment, 91, 3, 452-468.

WOCH, F. (2014): Ocena zmian wykorzystania przestrzeni wiejskiej w Polsce. Polish Journal of Agronomy, 18, 52-62.

WOCH, F., WOCH, R. (2014): Zmiany użytkowania przestrzeni wiejskiej w Polsce. Infrastruktura i Ekologia Terenów Wiejskich, 1, 1, 111-124.

\section{ACKNOWLEDGMENTS}

We give here our thanks to Tomasz Napierała $\mathrm{PhD}$ for his substantive help in writing this article as well as invaluable methodological tips. 